\title{
IMPLEMENTASI AKUNTABILITAS BERDASARKAN PADA PERSPEKTIF SHARIA ENTERPRISE THEORY (Studi Kasus pada Koperasi Syariah Mumtaz Tasikmalaya)
}

\author{
Yusuf Abdullah $^{1}$, Aa Willy Nugraha ${ }^{2}$ \\ ${ }^{1}$ Program Studi Magister Manajemen, Universitas Siliwangi, Email: yusuf.abdullah@unsil.ac.id \\ ${ }^{2}$ Program Studi Magister Manajemen, Universitas Siliwangi, Email: aawillynugraha@gmail.com
}

\begin{abstract}
Accountability is a form of responsibility that must be fulfilled by every organization/company. The concept of accountability is important not only for shareholders and another direct stakeholder but also for all parties involved, both employees and customers. Sharia cooperatives as a microfinance institution have an important role in funding and investing both from SMEs and individuals in accordance with the provisions of Islamic law. As an institution, Islamic cooperatives have accountability to be fulfilled by management as the responsibility to the members and shareholders for the mandate given by periodically reporting performance results and fulfilling the rights and obligations of stakeholders. Referring to the Islamic sharia system, Mumtaz sharia cooperative Tasikmalaya accountability is implemented with the Sharia Enterprise Theory (SET) perspective which is a trilogy of accountability, there are accountability to God, humans and nature. The research method used was qualitative method with a case study approach in one of the Islamic cooperatives in Tasikmalaya. The data collection technique was in-depth interviews with cooperative managers. The results of the study showed that the Mumtaz cooperative Tasikmalaya implements accountability based on Shariah Enterprise Theory perspective by fulfilling its obligations to God (spiritual), humans (economic and social), and nature (ecology) by carrying out various activities in accordance with the provisions of Islamic law.
\end{abstract}

Keywords: Accountability, Sharia Enterprise Theory, Sharia cooperative.

\begin{abstract}
ABSTRAK
Akuntabilitas merupakan bentuk pertanggungjawaban yang harus dipenuhi oleh setiap organisasi/perusahaan. Konsep akuntabilitas penting untuk dilaksanakan tidak hanya terhadap pemegang saham maupun dewan pengawas (direct stakeholder) melainkan terhadap semua pihak yang terlibat, baik itu karyawan maupun nasabah. Koperasi syariah sebagai salah satu lembaga keuangan mikro memiliki peran yang penting dalam pendanaan maupun investasi anggota koperasi, baik itu dari pelaku UMKM dan individu sesuai dengan ketentuan syariat Islam. Sebagai suatu lembaga, koperasi syariah memiliki akuntabilitas yang harus dipenuhi oleh manajemen sebagai tanggung jawab terhadap anggota koperasi maupun pemegang saham
\end{abstract}


atas amanah yang diberikan dengan melakukan pelaporan hasil kinerja secara periodik serta pemenuhan hak dan kewajiban para pemangku kepentingan. Mengacu pada sistem syariat Islam, akuntabilitas koperasi syariah Mumtaz Tasikmalaya diimplementasikan dengan perspektif Sharia Enterprise Theory (SET) yang merupakan trilogi akuntabilitas, yaitu bentuk akuntabilitas terhadap Tuhan, manusia dan alam/lingkungan. Metode penelitian yang digunakan adalah metode kualitatif dengan pendekatan studi kasus pada salah satu koperasi syariah di Kota Tasikmalaya. Teknik pengumpulan data dilakukan dengan melakukan wawancara secara mendalam terhadap pengelola koperasi. Hasil studi menunjukkan bahwa koperasi syariah Mumtaz Tasikmalaya mengimplementasikan akuntabilitas berdasarkan Sharia Enterprise Theory dengan memenuhi kewajibannya terhadap Tuhan (spiritual), manusia (ekonomi dan sosial), dan alam (ekologi) dengan melaksanakan beragam aktifitas sesuai dengan ketentuan syariat Islam.

Kata kunci: Akuntabilitas, koperasi syariah, Sharia Enterprise Theory (SET)

\section{PENDAHULUAN}

Koperasi memiliki peran penting sebagai salah satu roda penggerak perekonomian, terutama pada pembiayaan dan simpan pinjam bagi para anggotanya dengan azas kekeluargaan. Peran dan fungsi koperasi tidak hanya sebatas aktivitas ekonomi, tetapi sebagai manivestasi semangat kolektif, kebersamaan, dan prinsip keadilan dan gotong royong. Sebagaimana tercantum dalam Undang Undang No. 25 Tahun 1992 pasal 4 tentang perkoperasian, koperasi memiliki fungsi sebagai berikut:

1. Membangun dan mengembangkan potensi dan kemampuan ekonomi anggota pada khususnya dan masyarakat pada umumnya untuk meningkatkan kesejahteraan ekonomi dan sosialnya;

2. Berperan serta secara aktif dalam upaya mempertinggi kualitas kehidupan manusia dan masyarakat;

3. Memperkokoh perekonomian rakyat sebagai dasar kekuatan dan ketahanan perekonomian nasional dengan koperasi sebagai soko gurunya;

4. Berusaha untuk mewujudkan dan mengembangkan perekonomian nasional yang merupakan usaha bersama berdasarkan atas asas kekeluargaan dan demokrasi ekonomi.

Menurut data BPS (2019), jumlah koperasi dari tahun ke tahun mengalami peningkatan. Pada Tahun 2017, jumlah koperasi mencapai 152.172 unit tumbuh 0,66\% dibanding tahun sebelumnya. Jumlah koperasi telah meningkat 53,8\% seiring pertumbuhan 
ekonomi domestik. Diketahui provinsi dengan jumlah koperasi terbanyak di Indonesia adalah Jawa Timur, Jawa Tengah, dan Jawa Barat (Katadata.co.id)

Di sisi lain, BPS Tahun 2016 mencatat jumlah penduduk berkategori miskin mencapai 28,01 Juta jiwa (10,86\%). Oleh karena itu, untuk menekan angka kemiskinan, Koperasi Simpan Pinjam Syariah atau Koperasi Jasa Keuangan Syariah (KJKS) dan Unit Jasa Keuangan Syariah (UJKS) didirikan dengan harapan dapat meningkatkan kesejahteraan masyarakat Indonesia, khususnya pada kalangan masyarakat menengah kebawah dan mewujudkan keadilan sesuai dengan konsep Islam (Sofian, 2018: 753)

Koperasi sebagai badan usaha harus memiliki akuntabilitas yang baik dalam menciptakan kepercayaan terhadap stakeholder yang terlibat. Dalam konteks ini, akuntabilitas diartikan sebagai pertanggungjawaban atas manajemen dalam menjalankan tugasnya. Lebih lanjut lagi Mardiasmo (2005: 20) mendefinisikan akuntabilitas sebagai kewajiban pihak pemegang amanah (agent) untuk memberikan pertanggungjawaban, menyajikan, melaporkan, mengungkapkan segala aktifitasnya kepada pihak pemberi amanah (principal) yang memiliki hak dan kewenangan untuk meminta pertanggungjawaban tersebut. Berdasarkan hasil wawancara innews.co.id terhadap peneliti ahli utama Kementerian Koperasi dan UKM, Johnny W. Situmorang yang menyatakan bahwa permasalahan utama yang dialami oleh koperasi di Indonesia adalah masih lemahnya akuntabilitas dan transparansi, sehingga perlu adanya peningkatan, baik itu melalui pemerintah dengan mengeluarkan regulasi dalam hal peningkatan kapasitas sumber daya manusia koperasi di Indonesia serta dalam pengembangan digitalisasi koperasi dalam menghadapi era digital 4.0.

Fokus penelitian yaitu mengenai koperasi syariah yang berada di Tasikmalaya. Koperasi syariah memiliki prinsip bagi hasil dan investasi dengan berlandaskan pada hukum Islam (Syariah). Koperasi Syariah Mumtaz Tasikmalaya merupakan salah satu koperasi di Tasikmalaya yang pengelolaanya berdasarkan pada sistem syariah. Sebagai lembaga keuangan yang bergerak pada bidang pembiayaan dan investasi, koperasi Syariah Mumtaz Tasikmalaya memiliki keanggotaan yang terdiri dari individu dan pelaku Usaha Mikro, Kecil dan Menengah (UMKM), akuntabilitas koperasi menjadi poin penting dalam membangun kepercayaan masyarakat terlebih lagi dengan maraknya penyedia keuangan yang menawarkan pinjaman dengan bunga yang tinggi dan koperasi bodong. 
Penelitian pendahuluan mengenai akuntabilitas koperasi diantaranya adalah penelitian Siti Amelia, Gugus dan Didied, Irianto dan Affandy (2012) pada baitul maal wat tamwil; Shela Welly Arga, Aji Dedi Mulawarman (2018); Benedicta Adinsa Bella Savira dan Indira Januarti (2020); dan Asep Deni dan Ari Riswanto (2019) yang menyatakan bahwa pentingnya akuntabilitas dalam menjaga kepercayaan pemangku kepentingan (stakeholder) pada koperasi. Disamping itu, I.G. Lanang Agung, Ni Luh Gede Erni, dan Anantawikrama Tungga Atmadja (2015) menyimpulkan bahwa tidak hanya akuntabilitas tetapi transparansi koperasi harus dilakukan untuk menjaga kredibilitas koperasi.

Berdasarkan pada uraian latar belakang penelitian, maka penelitian ini bertujuan untuk mengetahui implementasi akuntabilitas pada koperasisyaruan Mumtaz Tasikmalaya berdasarkan pada perspektif Sharia Enterprise Theory (SET) yang meliputi hubungan dengan Tuhan, manusia dan alam/lingkungan.

\section{LITERATUR REVIEW}

Koperasi syariah merupakan bentuk koperasi yang mempunyai prinsip, tujuan, dan kegiatan usaha berdasarkan pada syariah Islam, dengan berpedoman pada kitabullah dan sunnah Nabi Muhammad SAW, yaitu Alquran dan Hadits. Disamping itu, koperasi syariah diartikan sebagai entitas bisnis koperasi dimana semua unit bisnis, produk dan sistem operasional dilakukan sesuai dengan fatwa Dewan Syariah Nasional (DSN). Dengan demikian, pada koperasi syariah tidak memiliki unsur riba, musyarakat, dan Ghara. Selain itu, badan usaha koperasi syariah tidak diizinkan untuk melakukan berbagai transaksi derivatif seperti lembaga keuangan islam lainnya.

\section{A. Koperasi Syariah Berdasarkan Perspektif Agency Theory}

Berdasarkan pada Peraturan Menteri Koperasi dan UKM Nomor 16 Tahun 2015 mengenai pelaksanaan simpan pinjam dan pembiayaan syariah oleh koperasi pasal 1 ayat 6 berbunyi bahwa prinsip syariah adalah prinsip hukum Islam dalam kegiatan usaha koperasi berdasarkan fatwa yang dikeluarkan oleh Dewan Syariah Nasional Majelis Ulama Indonesia (DSN-MUI). Sedangkan Ahmad Ifham (2010) menyatakan bahwa usaha koperasi syariah meliputi kegiatan usaha yang halal, baik dan bermanfaat (thayib) serta menguntungkan dengan sistem bagi hasil, dan tidak riba. 
Koperasi syariah berdasarkan pada Agency theory sebagaimana Alchian dan Demsetz Tahun 1972 dalam Ifham (2010) menjelaskan bahwa badan usaha koperasi dapat menjadi suatu penghubung antara beberapa individu, dengan kata lain hubungan kerja antara pemilik, termasuk didalamnya anggota koperasi dengan manajemen koperasi syariah. Setiap peran dan tindakan individu dalam koperasi terbagi berdasarkan spesifikasi preferensi dan kepercayaan. Koperasi sebagai suatu lembaga dan pengelola keuangan mikro terdiri dari beberapa entitas yang terlibat, yaitu pengelola dan anggota koperasi, dalam kata lain terdiri dari pemegang amanah (agent) dan pemberi amanah (principal) (Mursalim; 2005). Dapat dikatakan bahwa principal mendelegasikan pertanggungjawaban kepada agent, berupa amanah untuk melaksanakan tugas tertentu sesuai dengan kontrak kerja yang telah disepakati. Wewenang dan tanggungjawab agent maupun principal diatur dalam kontrak kerja atas persetujuan bersama (Siti Ameriska, et al, 2012: 29). Sutrisno (2002: 128) membuat model relasi antara agent dan prinsipal.

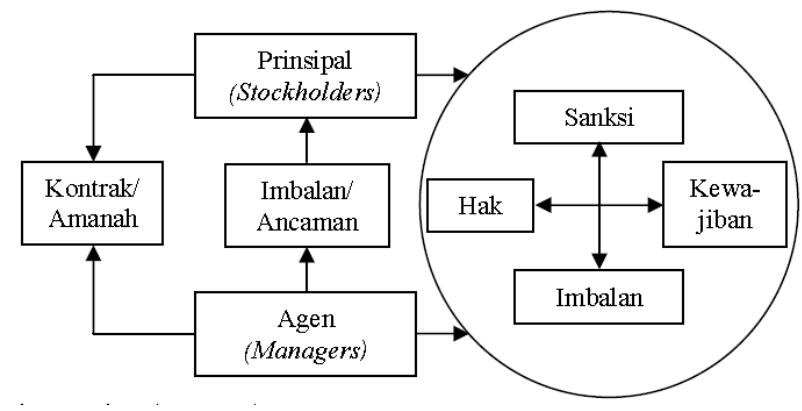

Sumber: Sutrisno, 2002: 128

\section{Gambar 1. Model Relasi antara Agent dan Principal}

Berdasarkan pada model di atas, Sutrisno (2002) menggambarkan keterlibatan antara manager di koperasi dengan prinsipal (stockholder) dimana pihak manager memberikan imbalan atau bahkan memberikan ancaman terhadap hasil kinerja usaha yang diamanahkan kepada manajer yang diatur dalam kontrak kerja. Kedua belah pihak memiliki komitmen bersama berupa pemenuhan hak dan kewajiban, serta memperoleh sanksi dan imbalan.

Koperasi syariah diartikan sebagai usaha koperasi yang meliputi semua kegiatan usaha yang halal, baik, bermanfaat serta menguntungkan dengan sistem bagi hasil dan tidak mengandung riba (Ahmad Ifham, 2010). Sedangkan menurut Kementerian Koperasi UKM sebagaimana undang-undang pasal 1 Tahun 2009, koperasi syariah adalah suatu bentuk 
koperasi yang segala kegiatan usahanya bergerak di bidang pembiayaan, simpanan, sesuai dengan pola bagi hasil syariah dan investasi.

\section{B. Akuntabilitas Berdasarkan Perspektif Sharia Enterprise Theory}

Akuntabilitas sebagai bentuk pertanggungjawaban moril manajemen koperasi terhadap anggota koperasi. Dengan demikian, maka manajer/pengelola koperasi harus memiliki transparansi terhadap segala aktifitas keuangan dan investasi sebagaimana tercantum dalam kontrak kerja. Manajer selaku agen memberikan informasi yang jelas terhadap perkembangan usaha, serta melaporkan temuan-temuan yang dapat membuat koperasi dalam posisi yang tidak menguntungkan.

Akuntabilitas dalam perspektif Sharia Enterprise Theory (SET) memiliki keseimbangan nilai egoistik, altruistik, materi dan nilai spiritual (Triyuwono, 2007). Dengan demikian, keseimbangan yang tercipta melibatkan beberapa pihak dan hubungan yang terjalin, sehingga membentuk 3 (tiga) dimensi akuntabilitas, yaitu akuntabilitas terhadap Tuhan, manusia, dan alam.

a. Akuntabilitas terhadap Tuhan diartikan sebagai upaya optimalisasi dari setiap sumber daya yang dianugerahkan kepada makhluknya merupakan suatu amanah yang didalamnya melekat tanggung jawab untuk menggunakannya sesuai dengan ketentuan syariat Allah, yang tertuang dalam kitab suci Al-Quran.

b. Akuntabilitas terhadap manusia diartikan sebagai hubungan antara manusia dimana satu pihak berperan sebagai pihak-pihak yang secara langsung memberikan kontribusi pada perusahaan baik dalam bentuk kontribusi keuangan maupun non-keuangan, selanjutnya disebut direct stakeholder yakni pihak yang sama sekali tidak memberikan kontribusi kepada perusahaan baik keuangan maupun non-keuangan, tetapi secara syari'ah mereka adalah pihak yang berhak untuk mendapatkan kesejahteraan dari perusahaan (indirect stakeholder) (Slamet; 2001).

c. Akuntabilitas terhadap Alam. Alam diartikan sebagai ekosistem vital yang memberikan kontribusi bagi kelangsungan hidup perusahaan, dengan kata lain keseimbangan dalam menjaga kelestarian alam adalah poin utama dalam menciptakan harmoni kehidupan yang selaras dan seimbang. Perusahaan akan tetap eksis apabila memperhatikan lingkungan alamnya. 


\section{METODE}

Penelitian ini bertujuan untuk mengetahui implementasi akuntabilitas koperasi berdasarkan pada Sharia Enterprise Theory (SET) dengan melaksanakan trilogi akuntabilitas yang meliputi akuntabilitas terhadap Tuhan, manusia dan alam/lingkungan.

Penelitian ini menggunakan metode survey dengan pendekatan kualitatif. Penelitian kualitatif diartikan sebagai metode penelitian yang berlandaskan pada filsafat positivisme, digunakan untuk meneliti pada kondisi objek yang alamiah, dimana peniliti adalah sebagai instrumen kunci, analisis data bersifat induktif dan hasil penelitian lebih menekankan pada makna daripada generalisasi (Sugiyono, 2012: 14). Jenis data pada penelitian ini terdiri dari data primer, yatu data hasil wawancara dengan pengelola koperasi syariah Mumtaz Tasikmalaya. Data sekunder diperoleh dari kajian pustaka yang dikutif sari buku referensi, jurnal penelitian, artikel dan berita online.

\section{HASIL DAN PEMBAHASAN}

Berdasarkan pada konsep Sharia Enterprise Theory mengenai perspektif baru terhadap akuntabilitas pada koperasi syariah, yang terdiri dari akuntabilitas terhadap Tuhan (spiritual), manusia (ekonomi dan sosial), dan alam (lingkungan). Dengan demikian, akuntabilitas berdasarkan perspektif SET bersifat holistik. Berikut adalah framework hasil penelitian mengenai implementasi akuntabilitas menurut perspektif SET pada koperasi Syariah Mumtaz Tasikmalaya sebagaimana terlihat pada Gambar 2 berikut..

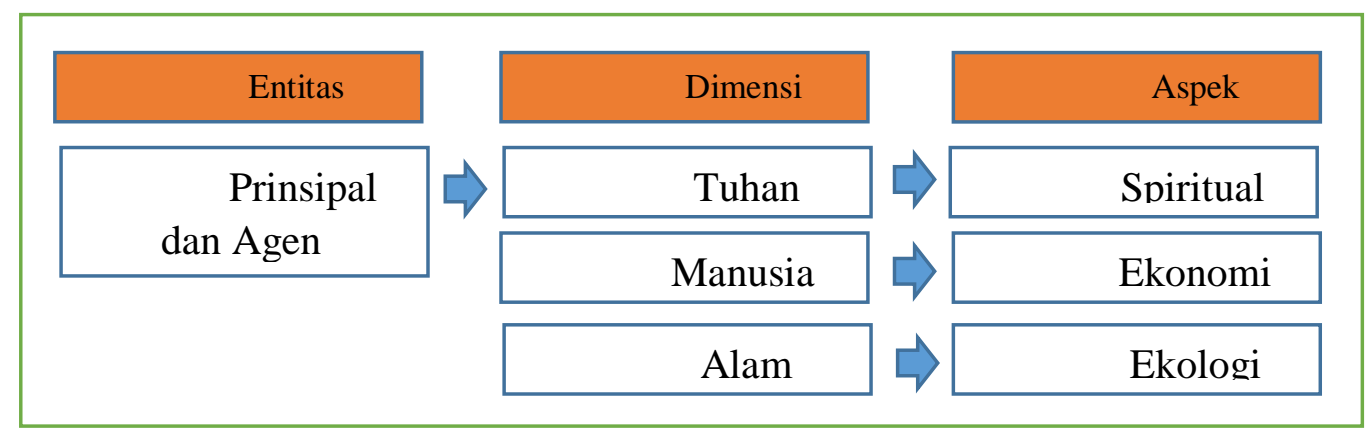

\section{Gambar 2: Framework Implementasi akuntabilitas berdasarkan pada SET pada Koperasi Syariah Mumtaz di Tasikmalaya}


Berdasarkan pada Gambar 2. di atas, berikut adalah uraian hasil penelitian pada Koperasi syariah Mumtaz di Tasikmalaya.

\section{Akuntabilitas Terhadap Tuhan: Spiritual}

Spiritual diartikan sebagai hubungan antara manusia dan tuhannya. Manusia mempecayai bahwa Tuhan yakni Alloh SWT merupakan pencipta dari semua alam semesta. Dengan demikian, akuntabilitas terhadap Tuhan diartikan sebagai pemenuhan kewajiban manusia sebagai seorang hamba $(a b d u)$ terhadap Tuhan-Nya (khaliq).

Akuntabalitas spiritual yang dilakukaan oleh koperasi syariah Mumtaz Tasikmalaya meliputi penyelenggaraan program-program keagamaan dalam meningkatkan iman dan taqwa kepada Allah SWT. Adapun kegiatan yang dilaksanakan yaitu melaksanakan pengajian keagamaan secara rutin setiap sebulan sekali, melaksanakan training motivasi, seperti ESQ dan Spiritual Outbond Training (SOT), seperti mabit dan i’tikaf bersama. Selain itu, memberikan pemahaman terhadap karyawan di Koperasi syariah Mumtaz Tasikmalaya dalam menanamkan nilai-nilai keislaman, seperti keikhlasan, kejujuran dan kooperatif dalam bekerja dan menanamkan sifat ihsan, yaitu memprioritaskan ibadah tanpa meninggalkan kewajiban sebagai seorang karyawan. Kegiatan-kegiatan tersebut tidak lain diselenggarakan sebagai upaya pemenuhan atas kewajiban terhadap Allah SWT.

Manifestasi akuntabilitas spiritual ini menghasilkan suatu prinsip bahwa segala aktivitas yang dilakukan adalah suatu bentuk ibadah kepada Allah, sehingga jalan yang ditempuh untuk tetap beribadah kepada-Nya adalah dengan menerapkan prinsip-prinsip syari'ah (humanis, emansipatoris, transendental dan teologikal) dalam aktivitas bisnis. Sebagaimana firman Allah SWT (Ad-Dzariat: 56).

"Dan tidaklah Aku menciptakan jin dan manusia, melainkan supaya mereka menyembah-Ku".

\section{Akuntabilitas Terhadap Manusia: Ekonomi dan sosial}

Koperasi memiliki peran dan fungsi dalam membangun potensi dan kemampuan ekonomi masyarakat terutama anggota koperasi dalam meningkatkan kesejahteraan ekonomi dan sosial. Sedangkan untuk mencapai tujuan tersebut, koperasi syariah Mumtaz Tasikmalaya dituntut untuk meningkatkan kemandiriannya dengan cara mengembangkan kegiatan usaha yang menguntungkan. Dalam pelaksanaanya, koperasi terdiri dari 2 (dua) entitas yang sama- 
sama bekerjasama dalam menjalankan usaha koperasi, yaitu pengelola koperasi (agen) dan anggota koperasi selaku prinsipal.

Sehingga, bentuk pertanggungjawaban yang dilakukan oleh pengelola koperasi syariah Mumtaz Tasikmalaya terhadap stakeholder yaitu dengan memperhatikan dampak ekonomi dan sosial. Aspek ekonomi dikukan dengan memberikan kinerja terbaik dalam mengelola usaha sehingga menghasilkan keuntungan yang baik bagi anggota. Oleh karenanya, sebagai laporan kepada prinsipal, koperasi syariah Mumtaz Tasikmalaya memberikan laporan kemajuan usaha yang meliputi perolehan laba dan SHU. Lebih lanjut lagi, koperasi syariah Mumtaz Tasikmalaya mengalokasikan keuntungan untuk membantu sesama yang membutuhkan dengan besaran persentase yang disepakati oleh kedua belah pihak. Disamping itu, aspek sosial yang terjadi adalah pihak manajemen koperasi syariah Mumtaz Tasikmalaya membangun sinergitas dengan para stakeholders dalam membangun kesejahteraan anggota sesuai dengan syariah. Sebagaimana firman Allah SWT (QS. Al-Jumuah: 10):

"Apabila telah ditunaikan shalat, maka berteberanlah di muka bumi, dan carilah karunia Allah dan Ingat Allah sebanyak-banyaknya supaya kamu beruntung”.

Disamping itu, membangun komunikasi yang baik sehingga terciptanya keselarasan, silaturahmi yang baik, solidaritas dan gotong royong sehingga menciptakan nilai-nilai keislaman yang ramah dan rahmatan lil alamin. Firman Allah SWT (QS Al Hujurat: 3).

"Hai manusia, sesungguhnya kami menciptakan kamu dari seorang laki-laki serta seorang perempuan dan menjadikan kamu berbangsa-bangsa dan bersuku-suku supaya kamu saling mengenal. Sesungguhnya orang yang paling mulia diantara kamu disisi Allah ialah orang yang paling bertakwa diantara kamu. Sesungguhnya Allah maha mengetahui lagi maha mengenal”.

\section{Akuntabilitas Terhadap Alam: Ekologi}

Alam dan lingkungan menjadi salah satu aspek yang penting dalam menciptakan harmonisasi kehidupan. Oleh karenanya, sebagai bentuk pertanggungjawaban Koperasi syariah Mumtaz Tasikmalaya terhadap alam dan lingkungan sekitar, pihak manajemen melakukan program aksi bersih-bersih lingkungan sekitar kantor koperasi, melakukan sosialisasi sanitasi lingkungan kepada anggota dan masyarakat sekitar, melakukan beberapa penyuluhan dan pendampingan usaha dalam bidang pertanian yang ramah lingkungan. 
Harmoni yang ditimbulkan dari menjaga lingkungan alam sekitar dapat menciptakan kenyamanan bagi semua pihak yang berada di lingkungan koperasi syariah Mumtaz Tasikmalaya.

Firman Allah SWT (QS. Al-Qashash: 77)

“...Dan janganlah kamu berbuat kerusakan di bumi. Sesungguhnya Allah tidak menyukai orang-orang yang berbuat kerusakan”.

\section{KESIMPULAN}

Pentingnya akuntabilitas sebagai kunci dalam menjaga kepercayaan stakeholders menjadi kewajiban yang mutlak dimiliki oleh badan usaha keuangan mikro seperti koperasi. Akuntabilitas berdasarkan pada Sharia Enterprise Theory (SET) memberikan perspektif terhadap akuntabilitas menjadi 3 (tiga) dimensi, yaitu akuntabilitas terhadap Tuhan, manusia dan alam. Berdasarkan hasil penelitian, berikut adalah kesimpulan mengenai implementasi akuntabilitas berdasarkan perspektif Sharia Enterprise Theory pada koperasi syariah Mumtaz Tasikmalaya.

1. Akuntabilitas terhadap Tuhan dilakukan dengan cara melaksanakan pengajian keagamaan secara rutin setiap sebulan sekali, melaksanakan training motivasi, seperti ESQ dan spiritual outbond training (SOT), seperti mabit dan i'tikaf bersama memberikan pemahaman terhadap karyawan di Koperasi syariah Mumtas Tasikmalaya dalam menanamkan nilai-nilai keislaman, seperti keikhlasan, kejujuran dan kooperatif dalam bekerja dan menanamkan sifat ihsan, yaitu memprioritaskan ibadah;

2. Akuntabilitas terhadap manusia dilakukan dengan membangun hubungan dengan sesama dengan memperhatikan aspek ekonomi dan sosial. Koperasi syariah Mumtaz Tasikmalaya memberikan laporan atas perkembangan usaha kepada stakeholders dan membangun sinergitas serta komunikasi interpersonal yang baik dengan anggota koperasi untuk menciptakan keselarasan;

3. Akuntabilitas terhadap alam mencakup kepedulian terhadap lingkungan dimana koperasi syariah Mumtaz Tasikmalaya berada. Menjaga lingkungan dan alam berarti menjaga titipan Allah SWT. Dengan demikian tercipta sebuah harmoni antara tempat kerja dengan lingkungan sekitar. 


\section{REFERENSI}

Asep, D., \& Ari, R. (2019). Akuntabilitas Dalam Pengelolaan Keuangan Koperasi Perguruan Tinggi (KPT) Mahasiswa. Jurnal STIE Dewantara. Pp. 115 - 122

Benedicta, A. B. Savira., \& Indira, J. (2020). Akuntabilitas koperasi simpan pinjam di Jawa Tengah. JEB. Volume 23 No. 1.Pp. $97-112$

I Gusti, L.A.M., Ni Luh Gede, E.S., Anantawikrama, T.A. (2015) Analisis Transparansi dan Akuntabilitas Pelaporan Keuangan Pada Koperasi Unit Desa di Kabupaten Buleleng (Studi Kasus Pada Koperasi Unit DesaTirta Luhur Desa Banyuning Buleleng). Jurnal Ilmiah Mahasiswa Akuntansi UNDIKSHA. Vol 3 No. 1. Pp. 1 - 10

Ifham, A.S. (2010). Buku Pintar Ekonomi Syariah. Bandung: PT Gramedia Pustaka Utama.

Kementerian Koperasi UKM sebagaimana Undang-Undang pasal 1 Tahun 2009

Mardiasmo. (2005). Akuntansi Sektor Publik. Yogyakarta: Andi.

Mursalim. (2005). Income Smoothing dan Motivasi Investor: Studi Empiris pada Investor di BEJ. SNA VIII Solo, 15-16 September 2005.

Peraturan Menteri Koperasi Dan Usaha Kecil Dan Menengah Republik Indonesia Nomor 16 /Per/M.Kukm/Ix/2015 Tentang Pelaksanaan Kegiatan Usaha Simpan Pinjam Dan Pembiayaan Syariah Oleh Koperasi.

Shela, W.A., Aji Dedi, M. (2018). Akuntabilitas Koperasi Syariah (Studi Kasus pada KANINDO Syariah Jatim). Jurnal Ilmiah Mahasiswa FEB. UNBRAW. Vol 2 No. 2. Pp. $1-20$.

Siti, A., Gugus, I., \& Didied P. Affandy. (2012). Akuntabilitas Pada Baitul Maal Wat Tamwil Ditinjau Dari Perspektif Shari'ate Enterprise Theory. Jurnal Ekonomi \& Keuangan Islam. Volume 2 No. 1. Hal. 27-39.

Sofian. (2018). Koperasi Syariah Sebagai Solusi Keuangan Masyarakat: Antara Religiusitas, Trend, Dan Kemudahan Layanan. ( $9^{\text {th }}$ Industrial Research Workshop and National Seminar. Polban. Pp. 752 - 758.

Sugiyono. (2012). Metode Penelitian Bisnis. Bandung: Alfabeta.

Sutrisno. (2002). Studi Manajemen Laba (Earnings Management): Evaluasi Pandangan Profesi Akuntansi, Pembentukan dan Motivasinya. Kompak. hal: 158-179.

Triyuwono, Iwan. (2006). Perspektif, Metodologi, dan Teori Akuntansi Syariah, Jakarta: PT Raja Grafindo Persada. 
Jurnal Ekonomi Syariah Vol. 5. No. 2. November 2020

p-ISSN 2548-5032 e-ISSN 2714-769X

Doi : 10.37058/jes.v5i2.2073

Undang Undang No. 25 Tahun 1992 pasal 4 tentang perkoperasian.

Viva, B,K. (2019). Berapa jumlah koperasi di Indonesia? dari https://databoks.katadata.co.id/datapublish/2019/07/25/berapa-jumlah-koperasi-diindonesia\# 